\title{
The Effect of Drama Activities on the Life Skills of Five-Year-Old Children
}

\author{
Remziye CEYLAN ${ }^{1} \&$ Feride GÖK ÇOLAK ${ }^{1}$ \\ ${ }^{1}$ Department of Early Childhood Education, Faculty of Education, Yildiz Technical University, İstanbul, Turkey \\ Correspondence: Feride GÖK ÇOLAK, Faculty of Education, Yildiz Technical University, İstanbul, Turkey.
}

Received: April 2, 2019

Accepted: May 24, 2019 Online Published: July 29, 2019

doi:10.5539/ies.v12n8p46

URL: https://doi.org/10.5539/ies.v12n8p46

\begin{abstract}
The purpose of this study is to investigate the effects of drama activities on the life skills of five-year-old children. Experimental design with pretest posttest control group was used in the study. The sample group of the study consisted of 32 children aged five years who were educated in a kindergarten in Istanbul province in the academic year of 2017-2018. In the study, "General Information Form" and "Preschool Life Skills Scale" were used as data collection tools. A total of 24 drama activities have been applied to the children in the experimental group for three times a week for eight weeks. After drama activities were completed, the same scale was applied as a post-test for the experimental and control group and four weeks later as a permanence test for the experimental group. As a result, drama activities have been found to be effective in supporting life skills.
\end{abstract}

Keywords: early childhood education, drama, drama activities, life skills

\section{Introduction}

Drama, without the prior written text, is the participants' own creative discoveries, novel ideas, memories and knowledge based on their knowledge and improvisations (San, 1999). In other words, drama is the response of participants to a stimulating material using their bodies or voices (Ömeroğlu-Turan \& Can-Yaşar, 1999). Creative drama in education is all about "improvisation, role playing, etc. by using theater or drama techniques, in a group work, individuals can experience a moment, an event, an idea, sometimes a training unit, sometimes an abstract concept or a behavior, by reorganizing the old cognitive patterns and observation, experience, the meaning of life in the "playful" processes in which the experiences are reviewed" (San, 1996, p. 149). In the early childhood period, there are experimental findings that reveal the importance and effect of drama on children's social-emotional (Aslan, 2008; Başdaş, 2017; Bayrakçı, 2007; Eti, 2010; Gültekin, 2014; Güner, 2008; Güven-Metin, 1999; Kılıç, 2017; Şahan-Aktan, 2018; Uysal, 1996), language (Çakır, 2008; Solmaz, 1997; Uyar, 1995) and cognitive domains (Erbay, 2009; Erdoğan, 2006 Kiyaker, 2017; Ölekli, 2009; Sezer, 2008) as well as creativity (Can-Yaşar, 2009; Ömeroğlu, 1990; Ömeroğlu, 1990) and the school adaptation (Şentürk-Berber, 2015).

In drama, there is an interaction between the real world and the fictional world. By the participant, drama is perceived as real and real emotions are experienced. From this point of view, the fiction is intertwined with reality. Participants enter and exit the fictional situations from the truth (Okvuran, 2001; Öztürk, 1999). Individuals who participate in drama studies learn the situations, events and relationships in the drama process. Participants use their knowledge and experience in the real world to create an imaginary world in drama and learn to examine events and relationships in defining situations and roles they design in drama (O'Neil \& Lambert, 1991). It can be said that preschool education is an indispensable element of the preschool period when it is considered as "a process of gaining an experience that gives the child a realistic and structured experience in a suitable environment" (Kuru-Turaşl1, 2014).

There are many reasons that increase the importance of drama. Önder (2001, pp. 39-44) stated that the increase in internal migration and its consequences, the increase in competition, the number of nuclear families and working mothers, and the increase in the number of divorces, thus, impair the social relations of children. It was also emphasized that children at risk should develop positive social relations and all development areas of the child should be fostered with the adoption of a holistic approach in education. Especially, it was stated that educational drama should be applied frequently in schools by taking the drama's role of supporting positive social relations into account. The researches carried out so far reported that drama provides children with the opportunities to experience different roles they see in the environment, various life styles, cultures and values as well as giving a 
chance to support their daily life skills and strengthening their abilities to overcome life problems (Aral \& Can-Yaşar, 2015, p. 128; Guli, 2004; Toye \& Prendiville, 2000).

\subsection{The Effect of Drama on Life Skills}

The concept of life skills has been defined by the World Health Organization (WHO, 1997) as skills that support psychosocial competence or performance (the ability of an individual to deal effectively with demands or challenges of everyday life). It is the ability to maintain a person's well-being and to show it in adaptable and positive behaviors when interacting with other people, their culture and environment (WHO, 1997, p.1). These skills are divided into three, namely, cognitive skills for knowledge analysis and use, personal skills for personal development and self-management, and interpersonal skills (UNICEF, 2003) to communicate and interact effectively with others. In addition to this classification, the World Health Organization (WHO, 1997) stated ten key skills including decision-making, problem-solving, creative thinking, critical thinking, effective communication, interpersonal relations, self-awareness, empathy, overcoming emotions, and coping with stress. A similar classification was carried out in educational environments by the US-based Academic, Social and Emotional Learning (CASEL), which aims to encourage children to succeed in school and in life. CASEL (2018) identified five key social and emotional competence groups.

- Self-awareness- accurately assessing one's own feelings, interests, values, and strengths;

- Self-management - regulating one's feelings to control stress and control impulses;

- Social awareness - to be able to create a perspective and empathy with others;

- Relationship skills - establishing and maintaining healthy and rewarding relationships resisting inappropriate social pressure, solving conflict; and

- Responsible Decision making - making decisions based on appropriate social norms respecting others, deciding on academic and social situations.

Life skills express a positive behavior that brings together life skills, knowledge, behavior, attitudes and values. Life skills are used for having a certain skill and knowledge, doing something positive or achieving a goal. The power of positive behaviors depends on the depth of the skills acquired by the individual (Subasree \& Radhakrishnan-Nair, 2014). International studies emphasize that early life skills need to be supported (Fahmie \& Luczynski, 2018; Hanley, Heal, Tiger, \& Ingvarsson, 2007; Hanley, Fahmie, \& Heal, 2014).

When the international studies on the subject are examined, it is seen that assessment tools for various age groups have been developed to assess life skills (Dhingraa \& Chauhan, 2017; Duerden, Witt, Fernandez, Bryant, \& Theriault, 2012; Kennedy, Pearson, Brett-Taylor, \& Talreja, 2014; Luckey \& Nadelson, 2011; Subasree \& Radhakrishnan-Nair, 2014). In addition, the studies carried out have primarily focused on life skills training, intervention (eg, Falligant \& Pence, 2017; Hanley, Heal, Tiger, \& Ingvarsson, 2007; Hanley, Fahmie, \& Heal, 2014 ; Jaskolski, 2017; Luczynski \& Hanley, 2013), however, it is noteworthy that most dealt with children with social behavior problems or with children with special needs who have lack of social skills.

Hanley, Heal, Tiger, and Ingvarsson (2007) aimed to develop and evaluate a classroom teaching program in their research to support life skills. To this end, they developed a program to prevent behavior problems in their research. In a class of 16 children aged 3-5, a comprehensive program that promoted positive social skills is evaluated. As a result of the application of the prepared program to the group, it showed a $74 \%$ decrease in problem behavior and a fourfold increase in preschool life skills. Another study was conducted by Luczynski and Hanley (2013). In this study, it expanded the preschool life skills (PLS) research by teaching functional communication and self-control skills to six children in the school failure risk group. The authors used a modified version of the PLS program to teach preschool teachers teacher attention, teacher assistance, and preferred materials, and behavioral skills training in small group training to tolerate delays and rejected requests. The small group PLS program has helped in the teaching of social skills and in the prevention of problem behaviors. A follow-up study by Luczynski, Hanley, and Rodriguez (2014) reported that all skills for all participants were not generalized in the classroom after the training, even after additional training sessions.

When the Turkish nation-wide studies on the subject are examined, it has been reached that there is only one scale (Yildirim, 2017) for life skills in early childhood and limited number of life skills training programs (Nazirzadeh, 2015; Kaya, 2016; Senturk-Aydin, 2013; Yeni, 2015; Yildirim, 2017). As there are limited studies focusing on children with special needs among the national studies that have investigated the effect of the program on children's development by developing life skills programs for preschool age children (Nazirzadeh, 2015; Kaya, 2016; Şentürk-Aydın, 2013; Yeni, 2015; Yıldırım, 2017), fewer studies have focused on children with normal development (eg, Kaya, 2016; Yıldırım, 2017). When the research questions of the available sources were 
examined, it was not observed that the effects of the drama activities integrated with life skills on life skills were investigated. Therefore, in this study, the effects of drama activities integrated with life skills on the life skills of five-year-old children were investigated.

\subsection{Problem of Research}

In this study, the effects of drama activities of preschool children aged five years on their life skills were investigated. In this study, the following questions were sought:

1) Is there a difference between the pretest scores related to the life skill levels of the children in the experimental and control groups?

2) Is there a difference between the posttest scores related to the life skill levels of the children in the experimental and control groups?

3) Is there a difference between posttest-pretest difference scores related to the life skill levels of the children in the control group?

4) Are there any differences between the pretest - posttest scores and retention scores of the children in the experimental group?

\section{Methodology of Research}

\subsection{General Background}

In this study, quasi-experimental design with pretest-posttest control group is used. The research design is shown as in Table 1.

Table 1. Quasi-experimental design with pretest-posttest control group

\begin{tabular}{lcccc}
\hline Group & Pretest & Treatment & Posttest & Retention \\
\hline Experiment & O1 & $\mathrm{X} 1$ & $\mathrm{O} 3$ & O5 \\
Control & O2 & & O4 & --- \\
\hline
\end{tabular}

Table 1 shows $\mathrm{O} 1$ and $\mathrm{O} 2$ pretest; $\mathrm{O} 3$ and $\mathrm{O} 4$ posttest administration; $\mathrm{O} 5$ refers only to the retention test performed on the experimental group. $\mathrm{X} 1$ is an independent variable that is applied to experimental subjects; that is, drama activities are combined with life skills (Köklü, Büyüköztürk, \& Bökeoğlu, 2007, p. 21).

\subsection{Sample}

The study group consisted of 32 five-year-old preschoolers who were attending to a kindergarten affiliated to Ministry of National Education in Istanbul / Turkey in the 2017-2018 academic year. Sixteen of the children in the study group were assigned as experimental group and 16 of them were assigned as control group. The children in the experimental and control groups were 8 boys and 8 girls. The frequency distributions regarding the children's demographical characteristics were given in Table 2.

Table 2. Frequency distributions regarding the children's demographical characteristics

\begin{tabular}{llcccccc}
\hline & & \multicolumn{5}{c}{ Group } \\
\cline { 3 - 8 } & & Experiment & \multicolumn{2}{c}{ Control } & \multicolumn{2}{c}{ Total } \\
\cline { 2 - 8 } Gender & Male & 8 & 50 & 8 & 50 & 16 & 50 \\
& Female & 8 & 50 & 8 & 50 & 16 & 50 \\
& Total & 16 & 100 & 16 & 100 & 32 & 100 \\
& 1 year or less & 6 & 37.5 & 3 & 18.75 & 9 & 28.13 \\
Attendance Period & 2 years & 6 & 37.5 & 10 & 62.5 & 16 & 50 \\
& 3 years & 4 & 25 & 3 & 18.75 & 7 & 21.88 \\
& Total & 16 & 100 & 16 & 100 & 32 & 100 \\
& Elementary & 2 & 12.5 & 0 & 0 & 2 & 6.25 \\
& Secondary & 1 & 6.25 & 0 & 0 & 1 & 3.13 \\
& High School & 3 & 18.75 & 9 & 56.25 & 12 & 37.5 \\
& Bachelor's degree & 9 & 56.25 & 7 & 43.75 & 16 & 50 \\
& Master's degree & 1 & 6.25 & 0 & 0 & 1 & 3.13 \\
\hline
\end{tabular}




\begin{tabular}{llcccccc}
\hline & Total & 16 & 100 & 16 & 100 & 32 & 100 \\
& Elementary & 0 & 0 & 1 & 6.25 & 1 & 3.13 \\
& Secondary & 1 & 6.25 & 0 & 0 & 1 & 3.13 \\
Father's Education & High School & 7 & 43.75 & 8 & 50 & 15 & 46.88 \\
& Bachelor's degree & 8 & 50 & 7 & 43.75 & 15 & 46.88 \\
& Total & 16 & 100 & 16 & 100 & 32 & 100 \\
\multirow{5}{*}{ Mother's Age } & $20-30$ & 2 & 12.5 & 2 & 12.5 & 4 & 12.5 \\
& $31-40$ & 13 & 81.25 & 13 & 81.25 & 26 & 81.25 \\
& $41-50$ & 1 & 6.25 & 1 & 6.25 & 2 & 6.25 \\
Father's Age & Total & 16 & 100 & 16 & 100 & 32 & 100 \\
& $31-40$ & 14 & 87.5 & 12 & 75 & 26 & 81.25 \\
& $41-50$ & 2 & 12.5 & 4 & 25 & 6 & 18.75 \\
& Total & 16 & 100 & 16 & 100 & 32 & 100 \\
\hline
\end{tabular}

\subsection{Instruments and Procedures}

"General Information Form" and "Preschool Life Skills Scale" were used as data collection tools.

- General Information Form: The general information form consists of items such as children's gender, attendance, parents' age and their level of education. This information was obtained from the directorate of the preschool institution and was collected with the consent of the parents.

- Preschool Life Skills Scale: Yildırım (2017) collected data from 400 children aged 60-72 months for the construct validity of the scale. As a result, regarding the construct validity of the scale, it has seven-factor structure and the seven factors obtained explain $62.32 \%$ of the total variance. There are 15 items in social life sub-factor, 7 items in responsibility factor, 6 items in self-awareness factor, 5 items in gender awareness factor, 4 items in decision-making factor, 4 items in survival factor and 4 items in survival factor and 3 items in self-care factor. The scale consists of 44 items and 7 factors in total. Data were collected from 312 children aged 60-72 months during the verification of the defined structure of the scale. The fit index values of the scale were determined as $\chi 2=$ $1374.34, \mathrm{sd}=868, \mathrm{X} 2 / \mathrm{sd}=1.58, \mathrm{CFI}=0.99, \mathrm{NNFI}=0.99$ and $\mathrm{NFI}=0.98, \mathrm{RMSEA}=0.043, \mathrm{SRMR}=0.047$. When the reliability analysis results were examined, Cronbach's alpha reliability coefficients were calculated by Yildirım (2017) as between 0.83 and 0.95 . In addition, the scale is filled out by teachers.

\section{Procedures and Data Collection Technique}

Since the quasi-experimental design with pre-test and post-test control group is used in the study, the following process has been applied:

1) Pretest (12-13 March 2018): The teachers in the experimental and control groups filled out the Preschool Life Skills Scale for each child.

2) Implementation of Activities (March 19, 2018 - May 11, 2018): In the experimental group, the educational drama program was implemented for 8 weeks (on Mondays, Wednesdays, Fridays) with 24 activities. The practicing researcher took a special drama course in addition to her applied and theoretical education during the undergraduate years. In this process, there was no treatment in the control group.

In the experimental group, the drama activities are listed below:

a) Before starting the experimental process, the objectives, content, duration and materials of the creative drama sessions were prepared.

b) The drama activities were prepared in order to improving children's social behaviors such as "the feeling of trust within the group, initiating and maintaining the relationship, effective listening, being able to cope with exclusion and ridicule, recognition of emotions, anger control, empathic behavior, using appropriate problem-solving strategies and communication and positive thinking".

c) In the first sessions, warm-up works for the purpose of acquainting the group were included in the drama sessions.

d) In order to make children feel more comfortable, drama studies were conducted in a classroom setting.

e) Care was taken to ensure that the stages of the drama were related to each other and to the targeted topic. The drama activities applied in Annex-1 are presented in table form.

3) Posttest: (14-15 May 2018): Following the implementation of the program, teachers in the experiment and 
control groups refilled out the Preschool Life Skills Scale for each child.

4) Retention test: (7-8 June 2018): About 3 weeks after the posttest scales were filled, the teachers in the experimental group filled out the Preschool Life Skills Scale once more for each child.

\section{Data Analysis}

In accordance with the purpose of the study, the pretest and posttest scores of the life skills of the children in the control group and the pretest and posttest scores of the children in the control group were entered in the SPSS-22 package program. Shapiro-Wilk analysis was used to test the normality assumption of the measurements. In the Shapiro-Wilk test, it was seen that the significance level for distribution was significant up to $\mathrm{p}<.05$ which was due to the small amount of data, meaning that the data sets calculated for the experimental and control groups do not display normal distribution.

When examining the differences between the groups, Mann Whitney U Test was used because the variables did not come from normal distribution. In the experimental group, Friedman's Two-Way ANOVA was used due the fact that two dependent variables did not come from the normal distribution in the analysis; in the case of significant differences, variables that differ from each other were determined by using Multiple Comparison Tests. In the control group, Wilcoxon Signed Ranks Test was used because the variables did not come from the normal distribution when examining the difference between two dependent variables.

\section{Results}

1st Sub-Problem: Is there a difference between pretest scores related to the life skill levels of the children in the experimental and control groups?

Table 3. Mann-Whitney U test results regarding the difference between preschool life skills scale sub-factors and total pretest scores of children in the control and experiment groups

\begin{tabular}{|c|c|c|c|c|c|c|c|c|c|c|}
\hline & & \multicolumn{6}{|c|}{ Group } & \multicolumn{3}{|c|}{ Mann Whitney U Test } \\
\hline & & $n$ & Mean & Median & Min & Max & sd & Mean Rank & $\mathrm{z}$ & $\mathrm{P}$ \\
\hline \multirow{3}{*}{$\begin{array}{l}\text { Social Life } \\
\text { Pretest }\end{array}$} & Experiment & 16 & 51.81 & 52 & 45 & 57 & 3.69 & 13.41 & & \\
\hline & Control & 16 & 56.88 & 58 & 39 & 72 & 10.04 & 19.59 & -1.868 & 0.062 \\
\hline & Total & 32 & 54.34 & 54 & 39 & 72 & 7.87 & & & \\
\hline \multirow{3}{*}{$\begin{array}{l}\text { Responsibility } \\
\text { Pretest }\end{array}$} & Experiment & 16 & 23.31 & 23 & 20 & 29 & 2.27 & 11.53 & & \\
\hline & Control & 16 & 28.56 & 29.5 & 20 & 35 & 4.8 & 21.47 & -3.01 & $0.003 *$ \\
\hline & Total & 32 & 25.94 & 24.5 & 20 & 35 & 4.56 & & & \\
\hline \multirow{3}{*}{$\begin{array}{l}\text { Self-awareness } \\
\text { Pretest }\end{array}$} & Experiment & 16 & 19.88 & 19 & 15 & 25 & 2.7 & 11.84 & & \\
\hline & Control & 16 & 23.81 & 23.5 & 15 & 29 & 4.02 & 21.16 & -2.825 & $0.005 *$ \\
\hline & Total & 32 & 21.84 & 21.5 & 15 & 29 & 3.92 & & & \\
\hline \multirow{3}{*}{$\begin{array}{l}\text { Gender awareness } \\
\text { Pretest }\end{array}$} & Experiment & 16 & 18.94 & 19 & 15 & 24 & 2.11 & 8.81 & & \\
\hline & Control & 16 & 24.38 & 25 & 23 & 25 & 0.89 & 24.19 & -4.728 & $0.001 *$ \\
\hline & Total & 32 & 21.66 & 23 & 15 & 25 & 3.19 & & & \\
\hline \multirow{3}{*}{$\begin{array}{l}\text { Decision making } \\
\text { Pretest }\end{array}$} & Experiment & 16 & 15 & 16 & 13 & 17 & 1.41 & 13.34 & & \\
\hline & Control & 16 & 17.13 & 18.5 & 11 & 20 & 3.34 & 19.66 & -1.951 & 0.051 \\
\hline & Total & 32 & 16.06 & 16 & 11 & 20 & 2.75 & & & \\
\hline \multirow{3}{*}{$\begin{array}{l}\text { Survival } \\
\text { Pretest }\end{array}$} & Experiment & 16 & 8.94 & 9 & 8 & 11 & 0.93 & 8.56 & & \\
\hline & Control & 16 & 16.5 & 17 & 11 & 19 & 2.13 & 24.44 & -4.873 & $0.001 *$ \\
\hline & Total & 32 & 12.72 & 11 & 8 & 19 & 4.17 & & & \\
\hline \multirow{3}{*}{$\begin{array}{l}\text { Self-care } \\
\text { Pretest }\end{array}$} & Experiment & 16 & 9.94 & 10 & 7 & 12 & 1.44 & 9.06 & & \\
\hline & Control & 16 & 14.5 & 15 & 10 & 15 & 1.41 & 23.94 & -4.707 & $0.001 *$ \\
\hline & Total & 32 & 12.22 & 12 & 7 & 15 & 2.71 & & & \\
\hline \multirow{3}{*}{$\begin{array}{l}\text { LS Total Score } \\
\text { Pretest }\end{array}$} & Experiment & 16 & 147.25 & 146.5 & 137 & 163 & 6.33 & 10 & & \\
\hline & Control & 16 & 180.88 & 183 & 134 & 210 & 21.28 & 23 & -3.923 & $0.001^{*}$ \\
\hline & Total & 32 & 164.06 & 153 & 134 & 210 & 23.03 & & & \\
\hline
\end{tabular}

$* \mathrm{p}<.05$.

According to Table 3, it is seen that there is no significant difference between the mean ranks of the means of life skill levels of the children in the experiment and control group related to "Social Life" sub-factor ( $p=.062>.05)$. 
There was a statistically significant difference between the groups in terms of "Responsibility" pretest scores $(p=0.003<.05)$. The "Responsibility" pretest score of the experimental group was significantly lower than the control group. There was statistically significant difference between the groups in terms of "Self-awareness" pretest scores $(\mathrm{p}=0.005<0.05)$. The "Self-awareness" pre-test score of the experimental group was significantly lower than the control group. There was a statistically significant difference between the groups in terms of pretest scores of "Gender awareness" $(\mathrm{p}=0.001<0.05)$. The "Gender awareness" pretest score of the experimental group was significantly lower than the control group. "Decision making" pretest scores of the experimental group were significantly lower than the control group. There was no statistically significant difference between the groups in terms of "Decision making" pretest scores $(\mathrm{p}=0.051>.05)$. There was a statistically significant difference between the groups in terms of Survival pretest scores $(\mathrm{p}=0.001<0.05)$. "Survival" pretest scores of the experimental group were significantly lower than the control group. There was a statistically significant difference between the groups in terms of "Self-care" pretest scores $(\mathrm{p}=0.001<0.05)$. "Self-care" pretest scores of the experimental group was significantly lower than the control group. There was a statistically significant difference between the groups in terms of LS total pretest scores $(\mathrm{p}=0.001<.05)$. The Life Skills total pretest score of the experimental group was significantly lower than the control group.

2nd Sub-Problem: Is there a difference between the posttest scores related to the life skill levels of the children in the experimental and control groups?

Table 4. Mann-Whitney U test results regarding the difference between preschool life skills scale sub-factors and total posttest scores of children in the control and experiment groups

\begin{tabular}{|c|c|c|c|c|c|c|c|c|c|c|}
\hline & & \multicolumn{6}{|c|}{ Group } & \multicolumn{3}{|c|}{ Mann Whitney U Test } \\
\hline & & $n$ & $\bar{X}$ & Median & Min & Max & $\mathrm{sd}$ & Mean Rank & z & $\mathrm{p}$ \\
\hline \multirow{3}{*}{$\begin{array}{l}\text { Social Life } \\
\text { Posttest }\end{array}$} & Experiment & 16 & 71.06 & 71.5 & 64 & 75 & 2.77 & 19.38 & & 0.082 \\
\hline & Control & 16 & 65.56 & 66.5 & 55 & 75 & 7.54 & 13.63 & -1.742 & \\
\hline & Total & 32 & 68.31 & 70.5 & 55 & 75 & 6.24 & & & \\
\hline \multirow{3}{*}{$\begin{array}{l}\text { Responsibility } \\
\text { Posttest }\end{array}$} & Experiment & 16 & 33.44 & 33 & 32 & 35 & 0.73 & 23.88 & & \\
\hline & Control & 16 & 28.5 & 30 & 22 & 33 & 3.58 & 9.13 & -4.538 & $0.001 *$ \\
\hline & Total & 32 & 30.97 & 33 & 22 & 35 & 3.57 & & & \\
\hline \multirow{3}{*}{$\begin{array}{l}\text { Self-awareness } \\
\text { Posttest }\end{array}$} & Experiment & 16 & 28.88 & 29 & 26 & 30 & 1.15 & 22.81 & & \\
\hline & Control & 16 & 24.87 & 26 & 19 & 29 & 3.44 & 10.19 & -3.855 & $0.001 *$ \\
\hline & Total & 32 & 26.87 & 28 & 19 & 30 & 3.24 & & & \\
\hline \multirow{3}{*}{$\begin{array}{l}\text { Gender awareness } \\
\text { Posttest }\end{array}$} & Experiment & 16 & 25 & 25 & 25 & 25 & 0 & 17.5 & & \\
\hline & Control & 16 & 24.69 & 25 & 22 & 25 & 0.87 & 15.5 & -1.437 & 0.151 \\
\hline & Total & 32 & 24.84 & 25 & 22 & 25 & 0.63 & & & \\
\hline \multirow{3}{*}{$\begin{array}{l}\text { Decision making } \\
\text { Posttest }\end{array}$} & Experiment & 16 & 19.31 & 20 & 17 & 20 & 1.14 & 19.53 & & \\
\hline & Control & 16 & 17.87 & 18 & 15 & 20 & 2.09 & 13.47 & -2.023 & $0.043^{*}$ \\
\hline & Total & 32 & 18.59 & 20 & 15 & 20 & 1.81 & & & \\
\hline \multirow{3}{*}{$\begin{array}{l}\text { Survival } \\
\text { Posttest }\end{array}$} & Experiment & 16 & 19 & 19 & 17 & 20 & 0.89 & 24.44 & & \\
\hline & Control & 16 & 14.56 & 14.5 & 12 & 17 & 1.59 & 8.56 & -4.833 & $0.001 *$ \\
\hline & Total & 32 & 16.78 & 17 & 12 & 20 & 2.59 & & & \\
\hline \multirow{3}{*}{$\begin{array}{l}\text { Self-care } \\
\text { Posttest }\end{array}$} & Experiment & 16 & 15 & 15 & 15 & 15 & 0 & 18.5 & & \\
\hline & Control & 16 & 14.5 & 15 & 12 & 15 & 1.03 & 14.5 & -2.1 & $0.036^{*}$ \\
\hline & Total & 32 & 14.75 & 15 & 12 & 15 & 0.76 & & & \\
\hline Life Skills & Experiment & 16 & 211.69 & 213.5 & 198 & 216 & 4.69 & 23.53 & & \\
\hline Total Score & Control & 16 & 190.56 & 191.5 & 166 & 212 & 15.16 & 9.47 & -4.25 & $0.001 *$ \\
\hline Posttest & Total & 32 & 201.12 & 208 & 166 & 216 & 15.39 & & & \\
\hline
\end{tabular}

$* \mathrm{p}<.05$.

Table 4 presents whether there was a significant difference between the sub-factors and skill levels of the Preschool Life Skills Scale posttest scores of the children in the experimental and control groups. The mean rank (19.38) of experimental group children's mean score $(\bar{X}=71.06)$ in terms of "Social Life" sub-factor was higher than those $(\bar{X}=65.56 ; 13.63)$ of the control group; however the difference was not significant $(\mathrm{p}=.082>.05)$. The mean rank (23.88) of experimental group children's mean score $(\bar{X}=33.44)$ in terms of "Responsibility" sub-factor was significantly higher than those $(\bar{X}=28.5 ; 9.13)$ of the control group $(\mathrm{p}=.001<.05)$. The mean rank 
(22.81) of experimental group children's mean score $(\bar{X}=28.88)$ in terms of "Self-awareness" sub-factor was significantly higher than those $(\bar{X}=24.87 ; 10.19)$ of the control group $(\mathrm{p}=.001<.05)$. The mean rank $(17.50)$ of experimental group children's mean score $(\bar{X}=25.00)$ in terms of "Gender awareness" sub-factor was higher than those $(\bar{X}=24.69 ; 15.50)$ of the control group but the difference was not significant $(\mathrm{p}=.151>.05)$. The mean rank (19.53) of experimental group children's mean score $(\bar{X}=19.31)$ in terms of "Decision making" sub-factor was significantly higher than those $(\bar{X}=17.87 ; 13.47)$ of the control group $(\mathrm{p}=.043<.05)$. The mean rank $(24.44)$ of experimental group children's mean score $(\bar{X}=19.00)$ in terms of "Survival" sub-factor was significantly higher than those $(\bar{X}=14.56 ; 8.56)$ of the control group $(\mathrm{p}=.001<.05)$. The mean rank $(18.50)$ of experimental group children's mean score $(\bar{X}=15.00)$ in terms of "Self-care" sub-factor was significantly higher than those $(\bar{X}=14.50$; $14.50)$ of the control group $(\mathrm{p}=.036<.05)$. The mean rank (23.53) of experimental group children's mean score $(\bar{X}$ $=211.69)$ in terms of "Preschool Life Skills Total" was significantly higher than those $(\bar{X}=190.56$; 9.47) of the control group $(p=.001<.05)$. After drama-based activities applied to the children in the experimental group, life skills levels in the sub-factors of the Preschool Life Skills Scale and in the sub-factors of Social Life and Gender awareness were found to be significantly higher than those of the control group.

3rd Sub-problem: Is there a difference between posttest-pretest difference scores related to the life skill levels of the children in the control group?

Table 5. Wilcoxon signed rank test results regarding the difference between preschool life skills scale sub-factors and total pretest-posttest mean scores of children in the control and experiment groups

\begin{tabular}{lccccccccc}
\hline & & & & & & & \multicolumn{3}{c}{ Wilcoxon Test } \\
\cline { 8 - 11 } & $n$ & Mean & Median & Min & Max & sd & Mean rank & Z & p \\
\hline Social Life Pretest & 16 & 56.88 & 58 & 39 & 72 & 10.04 & 3 & & \\
Social Life Posttest & 16 & 65.56 & 66.5 & 55 & 75 & 7.54 & 8.77 & -3.068 & 0.002 \\
Responsibility Pretest & 16 & 28.56 & 29.5 & 20 & 35 & 4.8 & 8.92 & & \\
Responsibility Posttest & 16 & 28.5 & 30 & 22 & 33 & 3.58 & 7.39 & -0.372 & 0.71 \\
Self-awareness Pretest & 16 & 23.81 & 23.5 & 15 & 29 & 4.02 & 5.5 & & \\
Self-awareness Posttest & 16 & 24.87 & 26 & 19 & 29 & 3.44 & 10.86 & -0.916 & 0.359 \\
Gender awareness Pretest & 16 & 24.38 & 25 & 23 & 25 & 0.89 & 6.5 & & \\
Gender awareness Posttest & 16 & 24.69 & 25 & 22 & 25 & 0.87 & 3.83 & -0.719 & 0.472 \\
Decision making Pretest & 16 & 17.13 & 18.5 & 11 & 20 & 3.34 & 5.33 & & \\
Decision making Posttest & 16 & 17.87 & 18 & 15 & 20 & 2.09 & 4.83 & -0.778 & 0.437 \\
Survival Pretest & 16 & 16.5 & 17 & 11 & 19 & 2.13 & 8.83 & & \\
Survival Posttest & 16 & 14.56 & 14.5 & 12 & 17 & 1.59 & 4.67 & -2.631 & 0.009 \\
Self-care Pretest & 16 & 14.5 & 15 & 10 & 15 & 1.41 & 2.67 & & \\
Self-care Posttest & 16 & 14.5 & 15 & 12 & 15 & 1.03 & 3.5 & -0.135 & 0.892 \\
LS Total Score Pretest & 16 & 180.88 & 183 & 134 & 210 & 21.28 & 5.63 & & \\
LS Total Score Posttest & 16 & 190.56 & 191.5 & 166 & 212 & 15.16 & 8.86 & -2.132 & 0.033 \\
\hline
\end{tabular}

${ }^{*} \mathrm{p}<.05$.

Table 5 shows results regarding whether there was a significant difference between Preschool Life Skills Scale sub-factors and total pretest-posttest mean scores of children in the control and experiment groups. The mean rank (23.16) of experimental group children's mean difference scores $(\bar{X}=19.25)$ regarding "Social Life" sub-factor was found out to be significantly higher than those $(\bar{X}=2.44 ; 9.84)$ of the control group ( $\mathrm{U}=21.50, \mathrm{p}=.000<.05)$. The mean rank (23.44) of experimental group children's mean difference scores $(\bar{X}=10.13)$ regarding "Responsibility" sub-factor was found out to be significantly higher than those $(\bar{X}=4.06 ; 9.56)$ of the control group (U=17.00, $\mathrm{p}=.000<.05)$. The mean rank (21.25) of experimental group children's mean difference scores $(\bar{X}$ $=9.00)$ regarding "Self-awareness" sub-factor was found out to be significantly higher than those $(\bar{X}=5.13 ; 11.75)$ of the control group $(\mathrm{U}=52.00, \mathrm{p}=.004<.05)$. The mean rank (19.74) of experimental group children's mean difference scores $(\bar{X}=6.06)$ regarding "Gender awareness" sub-factor was found out to be significantly higher than those $(\bar{X}=3.94 ; 13.24)$ of the control group $(\mathrm{U}=76.00, \mathrm{p}=.048<.05)$. The mean rank $(19.78)$ of experimental group children's mean difference scores $(\bar{X}=4.31)$ regarding "Decision making" sub-factor was found out to be significantly higher than those $(\bar{X}=2.56 ; 13.22)$ of the control group $(\mathrm{U}=75.00, \mathrm{p}=.045<.05)$. The mean rank (24.50) of experimental group children's mean difference scores $(\bar{X}=10.06)$ regarding "Survival" sub-factor was found out to be significantly higher than those $(\bar{X}=0.50 ; 8.50)$ of the control group $(U=.00, p=.000<.05)$. The 
mean rank (20.53) of experimental group children's mean difference scores $(\bar{X}=5.06)$ regarding "Self-care" sub-factor was found out to be significantly higher than those $(\bar{X}=3.00 ; 12.47)$ of the control group $(\mathrm{U}=63.50$, $\mathrm{p}=.014<.05)$. The mean rank (24.16) of experimental group children's mean difference scores $(\bar{X}=63.88)$ regarding Preschool Life skills Total and Sub-factors was found out to be significantly higher than those $(\bar{X}$ $=21.63 ; 8.84)$ of the control group $(\mathrm{U}=5.50, \mathrm{p}=.000<.05)$. It was seen that there was a significant difference between the posttest-pretest difference scores of the children in the experimental and control groups in terms of the Preschool Life Skills Scale Total and the sub-factors and the difference was in favor of the experimental group. It was concluded that the drama-based activities applied to the children in the experimental group increased their skill levels significantly compared to the children in the control group.

4th Sub-problem: Are there any differences between the pretest - posttest scores and retention scores of the children in the experimental group?

Table 6. Friedman's two-way anova and multiple comparisons test results regarding the difference between preschool life skills sub-factors and total posttest and retention test scores of experimental group children

\begin{tabular}{|c|c|c|c|c|c|c|c|c|c|c|c|}
\hline & & \multirow[b]{2}{*}{$n$} & \multirow[b]{2}{*}{ Mean } & \multirow[b]{2}{*}{ Median } & \multirow[b]{2}{*}{ Min } & \multirow[b]{2}{*}{ Max } & \multirow[b]{2}{*}{$\mathrm{Sd}$} & \multicolumn{2}{|c|}{$\begin{array}{c}\text { Friedman's } \\
\text { Two-Way ANOVA }\end{array}$} & \multicolumn{2}{|c|}{ Multiple Comparison } \\
\hline & & & & & & & & Mean Rank & Chi-square & $\mathrm{p}$ & \\
\hline \multirow{24}{*}{ 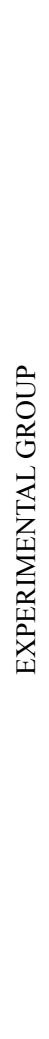 } & Social Life Pretest & 16 & 51.81 & 52 & 45 & 57 & 3.69 & 1 & & & \\
\hline & Social Life Posttest & 16 & 71.06 & 71.5 & 64 & 75 & 2.77 & 2.53 & 26.068 & 0.001 & $1-31-2$ \\
\hline & Social Life Retention Test & 16 & 71.44 & 72.5 & 68 & 74 & 2.06 & 2.47 & & & \\
\hline & Responsibility Pretest & 16 & 23.31 & 23 & 20 & 29 & 2.27 & 1 & & & \\
\hline & Responsibility Posttest & 16 & 33.44 & 33 & 32 & 35 & 0.73 & 2.47 & 26.068 & 0.001 & $1-31-2$ \\
\hline & Responsibility Retention Test & 16 & 33.5 & 33 & 31 & 35 & 1.15 & 2.53 & & & \\
\hline & Self-awareness Pretest & 16 & 19.88 & 19 & 15 & 25 & 2.7 & 1 & & & \\
\hline & Self-awareness Posttest & 16 & 28.88 & 29 & 26 & 30 & 1.15 & 2.41 & 27.263 & 0.001 & $1-31-2$ \\
\hline & Self-awareness Retention Test & 16 & 28.94 & 29 & 27 & 30 & 1.06 & 2.59 & & & \\
\hline & Gender awareness Pretest & 16 & 18.94 & 19 & 15 & 24 & 2.11 & 1 & & & $1-31-2$ \\
\hline & Gender awareness Posttest & 16 & 25 & 25 & 25 & 25 & 0 & 2.53 & 31.388 & 0.001 & \\
\hline & Gender awareness Retention Test & 16 & 24.94 & 25 & 24 & 25 & 0.25 & 2.47 & & & \\
\hline & Decision making Pretest & 16 & 15 & 16 & 13 & 17 & 1.41 & 1.03 & & & \\
\hline & Decision making Posttest & 16 & 19.31 & 20 & 17 & 20 & 1.14 & 2.56 & 25.964 & 0.001 & $1-31-2$ \\
\hline & Decision making Retention Test & 16 & 18.81 & 19 & 16 & 20 & 1.28 & 2.41 & & & \\
\hline & Survival Pretest & 16 & 8.94 & 9 & 8 & 11 & 0.93 & 1 & & & \\
\hline & Survival Posttest & 16 & 19 & 19 & 17 & 20 & 0.89 & 2.34 & 26 & 0.001 & $1-31-2$ \\
\hline & Survival Retention Test & 16 & 19.19 & 20 & 16 & 20 & 1.6 & 2.66 & & & \\
\hline & Self-care Pretest & 16 & 9.94 & 10 & 7 & 12 & 1.44 & 1 & & & \\
\hline & Self-care Posttest & 16 & 15 & 15 & 15 & 15 & 0 & 2.53 & 31.388 & 0.001 & $1-31-2$ \\
\hline & $\begin{array}{l}\text { Self-care } \\
\text { Retention Test }\end{array}$ & 16 & 14.88 & 15 & 13 & 15 & 0.5 & 2.47 & & & \\
\hline & LS Total Score Pretest & 16 & 147.25 & 146.5 & 137 & 163 & 6.33 & 1 & & & \\
\hline & LS Total Score Posttest & 16 & 211.69 & 213.5 & 198 & 216 & 4.69 & 2.59 & 24.667 & 0.001 & $1-31-2$ \\
\hline & LS Total Score Retention Test & 16 & 211.69 & 214 & 207 & 216 & 3.61 & 2.41 & & & \\
\hline
\end{tabular}

Table 6 provides results regarding whether there was any difference between life skills posttest scores of the children in the experimental group and the retention test scores after a certain period of time. Accordingly, it was found out that there was no significant difference between the mean rank of posttest mean scores of the life skill levels of the children in the experimental group related to the "Social Life" sub-factor and the mean rank of retention mean score according to $\mathrm{Z}=-.18, \mathrm{p}=.858>.05$. It was seen that there was no significant difference between the mean rank of posttest mean scores of the life skill levels of the children in the experimental group related to the "Responsibility" sub-factor and the mean rank of retention mean score according to $Z=-.37, p$ $=.710>.05$. Similarly, there was no significant difference between the mean rank of posttest mean scores of the life skill levels of the children in the experimental group related to the "Self-awareness" sub-factor and the mean rank of retention mean score according to $Z=-.06, p=.952>.05$. Also, there was no significant difference between the 
mean rank of posttest mean scores of the life skill levels of the children in the experimental group related to the "Gender awareness" sub-factor and the mean rank of retention mean score according to $Z=-1.00, p=.317>.05$. There was no significant difference between the mean rank of posttest mean scores of the life skill levels of the children in the experimental group related to the "Decision making" sub-factor and the mean rank of retention mean score according to $\mathrm{Z}=-1.08, \mathrm{p}=.281>.05$. No significant difference was seen between the mean rank of posttest mean scores of the life skill levels of the children in the experimental group related to the "Survival" sub-factor and the mean rank of retention mean score according to $\mathrm{Z}=-.58, \mathrm{p}=.565>.05$. There was no significant difference between the mean rank of posttest mean scores of the life skill levels of the children in the experimental group related to the "Self-care" sub-factor and the mean rank of retention mean score according to $Z=-1.00, p$ $=.317>.05$. Finally, there was no significant difference between the mean rank of posttest mean scores of the life skill levels of the children in the experimental group related to the Preschool Life Skills Scale Total and the mean rank of retention mean score according to $Z=-.68, p=.494>.05$. The researchers investigated whether children's posttest scores and their retention scores differed in order to test the probability that experimental group children's life skills levels, which had been improved using drama-based activities, decreased or somehow increased after certain period of time. It was concluded that there was no significant difference between the posttest scores of the children in the experimental group and the retention test scores in the total and sub-factors of Preschool Life Skills Scale; that is, they maintain their life skill levels that they have achieved despite the time passed.

The significant difference between the pretest and posttest scores in both the experimental group and the control group led to the need to investigate the difference between the groups in terms of change scores. Therefore, the results of the Mann Whitney U Test for the difference between the groups in terms of the change scores are given in Table 7.

Table 7. Mann Whitney $U$ test results regarding the difference between the groups in terms of change scores

\begin{tabular}{|c|c|c|c|c|c|c|c|c|c|c|}
\hline & & \multicolumn{6}{|c|}{ Group } & \multicolumn{3}{|c|}{ Mann Whitney U Test } \\
\hline & & $n$ & Mean & Median & Min & Max & $\mathrm{Sd}$ & Mean Rank & $\mathrm{z}$ & $\mathrm{p}$ \\
\hline \multirow{3}{*}{$\begin{array}{l}\text { Social Life } \\
\text { Change }\end{array}$} & Experiment & 16 & 19.25 & 19.5 & 12 & 25 & 3.75 & 22.59 & & \\
\hline & Control & 16 & 8.69 & 9.5 & -5 & 24 & 8.1 & 10.41 & -3.681 & $0.001 *$ \\
\hline & Total & 32 & 13.97 & 16 & -5 & 25 & 8.2 & & & \\
\hline \multirow{3}{*}{$\begin{array}{l}\text { Responsibility } \\
\text { Change }\end{array}$} & Experiment & 16 & 10.13 & 10.5 & 6 & 14 & 2.36 & 24.5 & & \\
\hline & Control & 16 & -0.06 & 1 & -7 & 4 & 3.26 & 8.5 & -4.842 & $0.001 *$ \\
\hline & Total & 32 & 5.03 & 5 & -7 & 14 & 5.88 & & & \\
\hline \multirow{3}{*}{$\begin{array}{l}\text { Self-awareness } \\
\text { Change }\end{array}$} & Experiment & 16 & 9 & 9.5 & 3 & 15 & 3.1 & 23.75 & & \\
\hline & Control & 16 & 1.06 & -0.5 & -2 & 7 & 3.19 & 9.25 & -4.388 & $0.001 *$ \\
\hline & Total & 32 & 5.03 & 6 & -2 & 15 & 5.08 & & & \\
\hline \multirow{3}{*}{$\begin{array}{l}\text { Gender awareness } \\
\text { Change }\end{array}$} & Experiment & 16 & 6.06 & 6 & 1 & 10 & 2.11 & 24.19 & & \\
\hline & Control & 16 & 0.31 & 0 & -3 & 2 & 1.4 & 8.81 & -4.692 & $0.001 *$ \\
\hline & Total & 32 & 3.19 & 2 & -3 & 10 & 3.41 & & & \\
\hline \multirow{3}{*}{$\begin{array}{l}\text { Decision making } \\
\text { Change }\end{array}$} & Experiment & 16 & 4.31 & 4 & 0 & 7 & 2.02 & 22.16 & & \\
\hline & Control & 16 & 0.75 & 0 & -4 & 9 & 3.17 & 10.84 & -3.469 & $0.001 *$ \\
\hline & Total & 32 & 2.53 & 3.5 & -4 & 9 & 3.18 & & & \\
\hline \multirow{3}{*}{$\begin{array}{l}\text { Survival } \\
\text { Change }\end{array}$} & Experiment & 16 & 10.06 & 10 & 8 & 12 & 1.18 & 24.5 & & \\
\hline & Control & 16 & -1.94 & -2 & -6 & 2 & 2.41 & 8.5 & -4.86 & $0.001 *$ \\
\hline & Total & 32 & 4.06 & 5 & -6 & 12 & 6.38 & & & \\
\hline \multirow{3}{*}{$\begin{array}{l}\text { Self-care } \\
\text { Change }\end{array}$} & Experiment & 16 & 5.06 & 5 & 3 & 8 & 1.44 & 24 & & \\
\hline & Control & 16 & 0 & 0 & -3 & 5 & 1.79 & 9 & -4.637 & $0.001 *$ \\
\hline & Total & 32 & 2.53 & 3 & -3 & 8 & 3.03 & & & \\
\hline \multirow{3}{*}{$\begin{array}{l}\text { LS Total Score } \\
\text { Change }\end{array}$} & Experiment & 16 & 64.44 & 67 & 47 & 77 & 8.41 & 24.5 & & \\
\hline & Control & 16 & 9.69 & 6 & -18 & 34 & 15.17 & 8.5 & -4.826 & $0.001 *$ \\
\hline & Total & 32 & 37.06 & 40.5 & -18 & 77 & 30.32 & & & \\
\hline
\end{tabular}

$* \mathrm{p}<.05$.

\section{Discussion and Conclusion}

In this study, it was investigated, by using experimental design, whether the drama activities applied to five-year-old children, who attend to a kindergarten and who have normal development, affect their development 
of life skills.

The most important result derived from the results of the study was that the experimental group and the control group post-test differences between the experimental group and the control group post-test scores are examined in the beginning of the study period in which the pretest scores of the experiment and control group are in favor of the control group and the drama activities in favor of the experimental group contribute to the development of the life skills of the children. In this sense, this study is in conformity with the findings of some national studies using similar experimental methods with children with normal development (Topçu-Bilir, 2019; Yıldırım, 2017).

According to research data; it was found that the total scores of the children in the experimental group and their scores in the sub-factors were significantly higher at the posttest than the children in the control group. These findings showed that drama activities were effective, and the findings were consistent with the literature (Fahmie \& Luczynski, 2018; Hanley, Heal, Tiger, \& Ingvarsson, 2007; Hanley, Fahmie, \& Heal, 2014; Kaya, 2016; Yildırım, 2017).

One of the results of the research was that there was no significant difference between the experimental group posttest and retention test scores. It was concluded that drama activities contribute positively to the life skills of the children in the experimental group and maintain their level of life skills despite time. These findings are consistent with the literature (Top̧̧u-Bilir, 2019; Yıldırım, 2017).

Another result of the study was that the difference between the pretest and posttest scores of the children in the control group was significant. The findings of Topçu-Bilir (2019) support this finding. As a result, it was stated that there was an increase in the difference between the pretest-posttest scores of the children in the control group despite the fact that the difference was not significant. This situation can be interpreted as Ministry of National Education Preschool Education Program applied to control group might have contributed to the children's life skills. The reason for this may be that one of the centers that should be present in the kindergartens as mentioned in the Ministry of National Education Preschool Education Program (2013) should be a dramatic play center, the necessity to include drama activities in the daily plans and to include life skills considering the gains and indicators in the program.

The children in the study group were randomly assigned to the experimental and control group. In the study, it was seen that there was a significant difference between the pretest scores of the experimental and control groups and this was in favor of the control group. Although the groups were not equal in terms of initial skill level, which is a limitation of this research, the researchers did not re-group the children since this situation was in favor of the control group.

\section{Suggestions}

Thanks to the findings of this study, the healing and improving role of drama comes into the prominence. For this reason, it is recommended that drama should be disseminated as a method in research with children. This research can be done with a mixed pattern and supported by qualitative data which may lead to more comprehensive results from the research. Therefore, the same problem situation can be examined in various designs. Application of such research to children with special needs may shed light on other studies. In addition, it can be applied in preschool education institutions where children from different socio-cultural levels continue and comparisons can be made with the obtained data.

\section{References}

Aral, N., \& Can-Yaşar, M. (2015). Özel Eğitimde Drama (Ed. A. Köksal-Akyol). Okul Öncesi Eğitimde Drama (pp. 125-142). Ankara: Hedef CS.

Aslan, E. (2008). Drama temelli sosyal beceri eğitiminin 6 yaş çocuklarının sosyal iliş̧kiler ve işbirliği davranışlarına etkisi. Yüksek lisans tezi. Adnan Menderes Üniversitesi, Sosyal Bilimler Enstitüsü, Aydın.

Başdaş, F. (2017). Drama Temelli Dijital Hikâye Anlatıcılı̆̆ Programının 6 Yaş Çocuklarının Bazı Sosyal Becerilerinin Gelişimine Etkisi. Adnan Menderes Üniversitesi, Sosyal Bilimler Enstitüsü, Aydın. https://doi.org/10.30803/adusobed.335056

Bayrakçı, M. (2007). Okulöncesinde yaratıcı drama etkinliklerinin iletişim becerilerinin gelişmesi üzerindeki etkisi. Yayınlanmamış yüksek lisans tezi, Kars Kafkas Üniversitesi Sosyal Bilimler Enstitüsü, Kars.

Çakır, B. (2008). Anasınıfı Türkçe dil etkinliklerinde yaratıcı drama yönteminin etkililiği. Yayınlanmamış Yüksek Lisans Tezi, Ondokuz Mayıs Üniversitesi Sosyal Bilimler Enstitüsü, Samsun.

Can-Yaşar, M. (2009). Anasınıfina devam eden altı yaş çocuklarının yaratıcı düşünme becerilerine drama eğitiminin etkisinin incelenmesi. Yayınlanmamış Doktora Tezi, Ankara Üniversitesi Fen Bilimleri Enstitüsü, 
Ankara.

CASEL. (2018). Core SEL Competencies. Retrieved from https:/casel.org/core-competencies/

Dhingraa, R., \& Chauhanb, K. S. (2017). Assessment of life-skills of adolescents in relation to selected variables. International Journal of Scientific and Research Publications, 7(8), 201-212.

Duerden, M. D., Witt, P. A., Fernandez, M., Bryant, M. J., \& Theriault, D. (2012). Measuring Life Skills: Standardizing the Assessment of Youth Development Indicators. Journal of Youth Development Bridging Research \& Practice, 7(1), 99-117. https://doi.org/10.5195/JYD.2012.155

Erbay, F. (2009). Anasınıfina devam eden altı yaş çocuklarına verilen yaratıcı drama ĕgitiminin çocukların işitsel muhakeme ve işlem becerilerine etkisinin incelenmesi. Selçuk Üniversitesi, Sosyal Bilimler Enstitüsü, Konya.

Erdoğan, S. (2006). Altı yaş grubu çocuklarına drama yöntemi ile verilen matematik ĕgitiminin matematik yeteneğine etkisinin incelenmesi. Yayınlanmamış Doktora Tezi, Ankara Üniversitesi, Fen Bilimleri Enstitüsü, Ankara.

Eti, İ. (2010). Drama etkinliklerinin okul öncesi eğitim kurumlarına devam eden 5-6 yaş grubu çocukların sosyal becerileri üzerine etkisi. Yayımlanmamış yüsek lisan tezi, Çukurova Üniversitesi Sosyal Bilimler Enstitüsü Okul Öncesi Eğitim Anabilim Dalı, Adana.

Fahmie, T. A., \& Luczynski, K. C. (2018). Preschool life skills: Recent advancements and future directions. Journal of Applied Behavior Analysis, 51, 183-188. https://doi.org/10.1002/jaba.434

Falligant, J. M., \& Pence, S. T. (2017). Preschool life skills using the response to intervention model with preschoolers with developmental disabilities. Behavior Analysis: Research and Practice, 17, $217-236$. https://doi.org/10.1037/bar0000056

Guli, L. A. (2004). The effects of creative drama-based intervention for children with deficits in social perception (Doctoral dissertation, University of Texas, Austin). Retrieved from https://repositories.lib.utexas.edu/handle/2152/1319

Gültekin, D. (2014). Yaratıcı Drama Eğitiminin 60-72 Aylık Çocukların Sosyal-Duygusal Gelişimine Etkisi (Malatya İli Örneği). Yayınlanmış Yüksek Lisans Tezi, İnönü Üniversitesi Eğitim Bilimleri Enstitüsü, Malatya.

Güner, A. Z. (2008). Eğitici Drama Uygulamalarının 5-6 Yaş Grubu Çocukların Sosyal-Duygusal Uyumlarına Etkisinin İncelenmesi. Yayınlanmış Yüksek Lisans Tezi, Marmara Üniversitesi, Eğitim Bilimleri Enstitüsü, İstanbul.

Güven-Metin, G. (1999). Dramanın 5-6 Yaş Çocuklarının Sosyal-Duygusal Gelişimlerine Etkisinin Incelenmesi. Yayınlanmış Yüksek Lisans Tezi, Marmara Üniversitesi, Eğitim Bilimleri Enstitüsü, İstanbul.

Hanley, G. P., Fahmie, T. A., \& Heal, N. A. (2014). Evaluation of the preschool life skills program in Head Start classrooms: A systematic replication. Journal of Applied Behavior Analysis, 47, 443-448. https://doi.org/10.1002/jaba. 132

Hanley, G. P., Heal, N. A., Tiger, J. H., \& Ingvarsson, E. I. (2007). Evaluation of a classwide teaching program for developing preschool life skills. Journal of Applied Behavior Analysis, 40, $277-300$. https://doi.org/10.1901/jaba.2007.57-06

Jaskolski, K. O. (2017). Discovering a Planet of Inclusion: Drama for Life-Skills in Nigeria, ArtsPraxis, 4(1), 39-53.

Kaya, İ. (2016) Yaşam becerileri programının (ybp) 4 yaş çocukların problem davranışlarına ve sosyal becerilerine etkisi. Yayınlanmamış Doktora Tezi, Selçuk Üniversitesi, Sosyal Bilimler Enstitüsü, Konya.

Kennedy, F., Pearson, D., Brett-Taylor, L., \& Talreja, V. (2014). The Life Skills Assessment Scale: Measuring life skills of disadvantaged children in the developing world. Social Behavior and Personality: An international journal, 42(2), 197-210. https://doi.org/10.2224/sbp.2014.42.2.197

Kılıç, Z. (2017). Yaratıcı dramaya dayalı etkinliklerin 60-66 aylık çocuklara değer kazandırılmasında etkisi. Yayınlanmamış Yüksek Lisans Tezi, Recep Tayyip Erdoğan Üniversitesi, Sosyal Bilimler Enstitüsü, Rize.

Kıyaker, S. (2017). 62-72 ay çocuklarının öz düzenleme becerisi üzerinde eğitici drama programının etkisinin incelenmesi. Okan Üniversitesi, Sosyal Bilimler Enstitüsü, İstanbul.

Köklü, N., Büyüköztürk, Ş., \& Bökeoğlu, Ç. Ö. (2007). Sosyal bilimler için istatistik. Ankara: Pegem 
Kuru-Turaşlı, N. (2014). Okul öncesi eğitimin tanımı, kapsamı ve önemi. In G. Haktanır (Ed.), Okul öncesi eğitime giriş (pp. 1-24, Gözden geçirilmiş 8. Baskı). Ankara: Anı Yayıncılık.

Luckey, K., \& Nadelson, L. S. (2011). Developing a life skills evaluation tool for assessing children ages 9-12. Journal of Youth Development, 6(1), 105-124. https://doi.org/10.5195/JYD.2011.202

Luczynski, K. C., \& Hanley, G. P. (2013). Prevention of problem behavior by teaching functional communication and self-control skills to preschoolers. Journal of Applied Behavior Analysis, 46, 355-368. https://doi.org/10.1002/jaba.44

Luczynski, K. C., Hanley, G. P., \& Rodriguez, N. M. (2014). An evaluation of the generalization and maintenance of functional communication and self-control skills with preschoolers. Journal of Applied Behavior Analysis, 47, 246-263. https://doi.org/10.1002/jaba.128

Nazirzadeh, M. J. (2015). Zihinsel engelli öğrencilere günlük yaşam becerilerinin ögrretiminde eğitsel tablet bilgisayar uygulamalarının etkililiğinin incelenmesi. Yayınlanmamış Yüksek Lisans Tezi, Orta Doğu Teknik Üniversitesi, Enformatik Enstitüsü, Ankara.

O’Neil, C., \& Lambert, A. (1991). Drama Structures A Pratical Handbook for Teachers. Chelpenman, Ingland.

Okvuran, A. (2001). Okulöncesi Dönemde Yaratıcı Drama. Çoluk Çocuk Dergisi, 3, 22-25

Ölekli, N. (2009). 5-6 Yaş çocuklarında matematiksel şekil algısı ve sayı kavramının gelişiminde drama yönteminin etkisi. Yayınlanmamış Yüksek Lisans Tezi, Selçuk Üniversitesi Sosyal Bilimler Enstitüsü, Konya.

Ömeroğlu, E. (1990). Anaokuluna giden 5-6 yaşındaki çocukların sözel yaratıcllıklarının gelişsiminde yaratıcı drama eğitiminin etkisi. Yayınlanmamış Doktora Tezi, Hacettepe Üniversitesi Sağlık Bilimleri Enstitüsü, Ankara.

Ömeroğlu-Turan, E., \& Can-Yaşar, M. (1999). Okulöncesi Eğitimde Drama Etkinlikleri. Gazi Üniversitesi Anaokulu/Anasınıfi Öğretmeni El Kitabı. Rehber Kitaplar Dizisi, İstanbul, Ya-Pa Yayın Pazarlama San. ve Tic. A.Ş. s. 91-110.

Önder, A. (2001). Yaşayarak Öğrenme için Eğitici Drama Kuramsal Temellerle Uygulama Teknikleri ve Örnekleri. İstanbul: Epsilon Yayıncilık.

Öztürk, A. (1999). Yaratıcı Drama ve Müzik. Türkiye, 1, 76-81.

Şahan-Aktan, B. (2018). 48-72 aylık çocuklar için psikolojik dayanıklllık ölçeğinin geliştirilmesi ve eğitici drama temelli psikolojik dayanıklllı programının etkisinin incelenmesi. Marmara Üniversitesi, Eğitim Bilimleri Enstitüsü, İstanbul.

San, İ. (1996). Yaratıcılığı geliştiren bir yöntem ve yaratıcı bireyi yetiştiren bir disiplin: Eğitsel yaratıcı drama. Yeni Türkiye Dergisi, 2(7), 148-160.

San, İ. (1999). Türkiye'de yaratıcı drama çalışmalarının dünü ve bugünü. Cumhuriyet ve Çocuk, 2, 267-273.

Şentürk-Aydın, R. (2013). Yaşam becerileri psikoeğitim programının boşanmış aile çocuklarının uyum düzeylerine etkisi. Yayınlanmamış Yüksek Lisans Tezi, Ankara Üniversitesi, Eğitim Bilimleri Enstitüsü, Ankara.

Şentürk-Berber, S. (2015). Okul öncesi 5 yaş çocukları için eğitici drama temelli okula uyum programının değerlendirilmesi. Yayınlanmamış Yüksek Lisans Tezi, Marmara Üniversitesi, Eğitim Bilimleri Enstitüsü, İstanbul.

Sezer, T. (2008). Okul öncesi eğitimi alan beş yaş grubu çocuklara sayı ve işlem kavramlarını kazandırmada drama yönteminin etkisinin incelenmesi. Yayınlanmamış Yüksek Lisans Tezi, Abant İzzet Baysal Üniversitesi Sosyal Bilimler Enstitüsü, Bolu.

Solmaz, F. (1997). 6 yaş grubu çocukların alıcı ve ifade edici dil gelişimine yaratıcı drama eğitiminin etkisi. Yayınlanmamış Yüksek Lisans Tezi, Gazi Üniversitesi, Ankara.

Subasree, R., \& Radhakrishnan-Nair, A. (2014). The Life Skills Assessment Scale: the construction and validation of a new comprehensive scale for measuring Life Skills. IOSR Journal of Humanities and Social Science (IOSR-JHSS), 19(1), 50-58. https://doi.org/10.9790/0837-19195058

Topçu-Bilir, Z. (2019). Yaşam becerileri programinin beş yaş çocuklarinin yaşam becerileri, benlik algilari ve sosyal duygusal uyum düzeylerine etkisi. Yayınlanmamış Yüksek Lisans Tezi, Hacettepe Üniversitesi, Eğitim Bilimleri Enstitüsü, Ankara. 
Toye, N., \& Prendiville, F. (2000). Drama and traditional story for the early years. London \& New York: Routledge.

UNICEF. (2003). Life skills. Retrieved from https://www.unicef.org/lifeskills/index_7308.html

Uyar, N. (1995). Anaokuluna devam eden 60-72 aylık çocuklarda destekleyici olarak uygulama eğitiminde drama programının çocukların dil gelişsimine etkisinin incelenmesi. Yayınlanmamış Yüksek Lisans Tezi, Hacettepe Üniversitesi Sağlık Bilimleri Enstitüsü, Ankara.

Uysal, F. N. (1996). Anaokuluna giden 5-6 yaş grubu çocuklarda yaratıcı drama çalışmalarının sosyal gelişim alanına olan etkisinin incelenmesi. Yayınlanmamış Yüksek Lisans Tezi, Ankara Üniversitesi, Sosyal Bilimler Enstitüsü, Ankara.

WHO. (1997). Life Skills Education For Children and Adolescents in Schools. References from http://www.searo.who.int/entity/mental_health/documents/who-mnh-psf-93.7Arev2/en/

Yeni, S. (2015). Zihinsel engelli öğrencilere günlük yaşam becerilerinin öğretiminde eğitsel tablet bilgisayar uygulamalarının etkililiğinin incelenmesi. Yayınlanmamış Doktora Tezi, Orta Doğu Teknik Üniversitesi, Fen Bilimleri Enstitüsü, Ankara.

Yıldırım, Y. (2017). Anasınıfina devam eden çocuklara uygulanan yaşam becerisi eğitim programının çocukların yaşam becerilerine ve sosyal uyumlarına etkisi (Doktora Tezi). Gazi Üniversitesi Eğitim Bilimleri Enstitüsü. Ankara.

\section{Note}

Note 1. A part of this study was presented at " 5 th International Symposium on Social Humanities and Administrative Sciences", as an oral presentation in on October, 25-27, 2018, Istanbul, Turkey.

\section{Copyrights}

Copyright for this article is retained by the author(s), with first publication rights granted to the journal.

This is an open-access article distributed under the terms and conditions of the Creative Commons Attribution license (http://creativecommons.org/licenses/by/4.0/). 